\title{
Menata Ulang Bisnis F\&B Pasca Pandemi (Studi Kasus: Strategi Komunikasi Pemasaran Sate Taichan “Goreng”)
}

\author{
Niko Al-Hakim \\ Fakultas Komunikasi Institut Komunikasi dan Bisnis LSPR \\ Email:20210330079@lspr.edu
}

\begin{abstract}
ABSTRAK
Saat pandemi Covid-19 terjadi, praktik bisnis di seluruh dunia pun terganggu. Dari banyaknya toko ritel yang tutup hingga pasar tradisional, para pelaku bisnis, baik pemain besar maupun kecil menerima pukulan besar yang sama dalam implikasi yang berbeda. Memahami efek global utama yang disebabkan oleh satu virus yang dimulai dari pasar tradisional kecil di Wuhan, F\&B didorong untuk tidak hanya beradaptasi, tetapi juga untuk memikirkan langkah maju sambil memastikan mereka tidak kehilangan karyawan dan konsumen mereka melalui strategi komunikasi pemasaran terintegrasi digital yang kreatif. Penelitian kualitatif deskriptif ini bertujuan untuk memberikan analisis mendalam tentang strategi komunikasi pemasaran Sate Taichan "Goreng" (STG) selama Pembatasan Sosial Skala Besar (PSBB) di Indonesia yang dilakukan di beberapa kota dengan potensi ekonomi tinggi di Indonesia. Dalam penerapannya, STG menggunakan 8 (delapan) model bauran komunikasi pemasaran. Hasilnya, Sate Taichan "Goreng" berhasil dioperasikan dengan penyesuaian normal baru dengan dukungan penerapan strategi cross-channel komunikasi pemasaran yang berkelanjutan. Selain itu, kehidupan normal baru yang mengarah pada "Stay at home" ekonomi juga dinilai memainkan peran utama bagi keberhasilan operasi bisnis STG selama PSBB.
\end{abstract}

Kata-kata Kunci: Komunikasi Pemasaran, Digitalisasi, Luar jaringan, Pandemi, Bisnis

\section{Reimagining F\&B Business Post-Pandemic (Study Case: Sate Taichan “Goreng” Marketing Communications Strategy)}

\begin{abstract}
As the Covid-19 pandemic has happened, business practices across the globe were disrupted. From many closing retails stores to traditional markets, business people, both big and small players took the same big hit in different implications. Understanding the major global effect caused by one single virus that started from a small traditional market in Wuhan, $F \& B$ were being pushed to not only to adapt, but also to think a step forward while making sure they're not losing their employees and consumers through creative digital-integrated marketing communications strategy. This descriptive qualitative research is aimed to provide an in-depth analysis of Sate Taichan "Goreng" (STG) marketing communications strategy during the Indonesia's Large-Scale Social Restrictions (PSBB) conducted in the country's several highly-economic potential cities. In practice, STG uses 8 (eight) marketing communication mix models. The result was Sate Taichan "Goreng" has successfully been operated under the new-normal adjustments with the support of the continuous cross-channel marketing communications strategy implementation. Apart from that, the new normal life that leads into the "Stayat-Home" economy is also considered to play major role for STG's successful business operations during the PSBB.
\end{abstract}

Keywords: Marketing Communications, Digitalization, Online, Pandemic Business

Published: Maret 2021

ISSN: 2622-5476 (cetak), ISSN: 2655-6405 (online) Website: https://jurnal.amikom.ac.id/index.php/pikma 


\section{PENDAHULUAN}

Sejak pertama kali dilaporkan di Wuhan, China, kemudian menyebar ke seluruh dunia dan ditetapkan sebagai pandemi global oleh World Health Organization (WHO), pandemi Covid-19 telah memberikan perubahan besar, berdampak pada hampir semua aspek manusia secara global. Beberapa gejala yang ditimbulkan oleh virus baru ini antara lain demam tinggi, gangguan pernafasan, batuk, dan pada kasus yang lebih parah, virus menyebabkan infeksi paru-paru bahkan pneumonia, sindrom pernafasan akut, gagal ginjal, dan kematian. Memahami kekhawatiran utama tersebut, pada tanggal 30 Januari 2021, World Health Organization pada hari Kamis mengeluarkan deklarasi darurat global, yang disebut "Public Health Emergency of International Concern", disingkat PHEIC (Douglas \& Staudenmaier, 2020).

Indonesia melaporkan kasus Covid-19 pertama pada Maret 2020 dan hingga saat ini kasusnya terus meningkat. Pada 26 Januari 2021, ditandai satu juta kasus positif Covid-19 dengan jumlah kematian telah melebihi dari 28.000 orang (Putwiliani, 2021).

Mengingat dengan adanya urgensi akan penanganan yang serius, pada tanggal 13 Maret 2020, Presiden Republik Indonesia, Joko Widodo membentuk Gugus Tugas Percepatan Penanganan
Covid-19 di Indonesia. Tujuan dari satgas tersebut adalah agar pemerintah dalam memimpin penanganan penyebaran pandemi di tanah air yang kemudian dinyatakan sebagai negara non bencana alam berdasarkan Peraturan Presiden 12/2020 pada April 2020 (Arifin, 2020)

Lebih lanjut, untuk menekan peningkatan kasus positif Covid-19 di seluruh wilayah, telah dikeluarkan peraturan Pembatasan Sosial Skala Besar (PSBB) di bawah Kementerian Kesehatan Republik Indonesia pada 3 April 2020. Sebagai pusat penyebaran virus tersebut dengan jumlah kasus terbanyak pada saat itu, DKI Jakarta menjadi provinsi pertama yang diberikan izin dalam pelaksanaan ketentuan PSBB, berdasarkan Keputusan Menteri Kesehatan Republik Indonesia Nomor HK.01.07 / MENKES / 239/2020 tentang Peraturan Menteri Kesehatan Republik Indonesia. Penetapan PSBB di Provinsi DKI Jakarta (Hakim, 2020).

Pemberlakuan peraturan yang bersifat membatasi atau PSBB telah menyebabkan perubahan besar dalam kehidupan manusia, menyebabkan segala bentuk interaksi sosial seperti pekerjaan, sekolah, dan interaksi sosial masif lainnya dilarang. Selain itu, pandemi juga menyebabkan perubahan di sektor ekonomi. Badan Pusat Statistik (BPS) menyatakan bahwa dunia usaha mengalami penurunan jumlah pendapatan usaha yang disebabkan oleh penurunan 
penjualan dan produksi yang kemudian menyebabkan orang kehilangan pekerjaan karena inisiatif perusahaan untuk bertahan hidup (Badan Pusat Statistik, 2020). Sebuah survei dari Kementerian Tenaga Kerja menyatakan bahwa pada Agustus 2020, dari 1.105 perusahaan yang mengikuti survei, $47,4 \%$ mayoritas mengklaim bahwa Covid-19 berbahaya bagi kelangsungan bisnis (Ridhoi, 2021)

Dengan terbatasnya interaksi sosial di masyarakat yang kemudian juga membatasi mobilitas usaha di berbagai sektor dan industri, salah satu industri yang mengalami dampak paling besar dari pandemi ini adalah industri Food and Beverages $(F \& B)$. Hasil survei BPS mencatat dari $82,5 \%$ pelaku usaha yang mengaku terkena pandemi, sektor usaha akomodasi dan $F \& B$ menduduki peringkat 1 sebagai sektor usaha dengan penurunan pendapatan terbesar $(92,47 \%)$ (Bayu, 2020). Penurunan angka pendapatan sektor $F \& B$ yang cukup besar tersebut disebabkan oleh beberapa faktor seperti kondisi ekonomi yang tidak menentu, fenomena infodemik, dan regulasi PSBB yang membuat masyarakat mempertimbangkan kembali pilihannya dalam membeli dan makan di luar rumah. Menurut hasil survei internal Moka, dari 17 kota yang diamati, Terdapat 13 kota yang mengalami penurunan pendapatan paling tajam untuk industri $F \& B$, dengan Bali dan Surabaya diklaim sebagai yang mengalami penurunan tertinggi, dengan angka penurunan 26\% dan 18\% (Moka Indonesia, 2020). Lebih lanjut, Gabungan Pengusaha Makanan \& Minuman Indonesia (GAPMMI) bahkan memperkirakan pertumbuhan industri $F \& B$ hanya akan mengalami angka 4-5\% selama pandemi Covid-19 (Prakoso, 2020). Seiring bisnis yang terus terganggu dan perubahan pola konsumsi pelanggan, pemilik bisnis $F \& B$ didorong untuk tidak hanya beradaptasi, tetapi juga berinovasi untuk memastikan kelangsungan bisnis mereka dengan melihat kemungkinan baru, model bisnis baru dan menanamkan cara "normal baru" untuk keberlanjutan dan ketahanan bisnis $F \& B$ ke depan.

Di sisi lain, pandemi juga telah membawa negara, termasuk Indonesia memasuki dimensi baru perubahan industri yaitu Revolusi Industri Keempat (Industri 4.0) dalam bentuk ekonomi digital. Perkembangan teknologi informasi yang dibarengi dengan peningkatan jumlah internet dan penggunaannya telah membawa perekonomian Indonesia memasuki era baru, era ekonomi digital ditunjukkan dengan munculnya model bisnis baru dalam meningkatkan customer experience seiring dengan semakin efisiennya kegiatan bisnis dan aktivitas bisnis responsif, menyesuaikan dengan kebutuhan pasar (SMERU, nd). 
Secara konseptual, Knickrehm, dkk. (2016) mendefinisikan ekonomi digital sebagai bagian dari total output ekonomi yang diperoleh dari sejumlah besar input "digital". Konsep tersebut pertama kali diperkenalkan pada tahun 1990-an terutama dengan munculnya internet yang kemudian menjadi tumpuan bagi pertumbuhan ekonomi digital. Perkembangan teknologi informasi telah mengubah perilaku masyarakat dalam bertransaksi, memungkinkan peningkatan penggunaan alat pembayaran nontunai seiring dengan maraknya penggunaan e-money sebagai alat pembayaran. Ekonomi digital diyakini dimulai dengan digitalisasi dan digitalisasi yang mengarah pada penggunaan data digital oleh para pemangku kepentingan, termasuk pemilik bisnis untuk mengembangkan model bisnis baru dan menciptakan pengalaman pelanggan yang inovatif.

Memahami pentingnya digitalisasi, secara umum sekitar $47,75 \%$ perusahaan telah mengadopsi penggunaan internet dan Teknologi Informasi (TI) untuk pemasaran online bahkan sebelum pandemi terjadi. Kemudian, sekitar 5,67\% perusahaan baru mengikuti strategi yang sama dengan mendigitalkan bisnisnya secara langsung selama pandemi (BPS, 2020).

Penelitian ini menggunakan dua penelitian terdahulu yang memiliki keterkaitan dengan objek penelitian sebagai referensi. Penelitian pertama ditulis oleh Liliyana pada tahun 2020 dengan judul, "Implementasi Bauran Promosi Dalam Usaha Kuliner Rumah Makan Bumbu Desa Ciledug Pada Masa Pandemi Covid-19”. Tujuan penelitian ini adalah untuk menganalisis dampak yang ditimbulkan dari penerapan strategi bauran pemasaran Rumah Makan Bumbu Desa Ciledug pada saat pandemi Covid-19. Lebih lanjut Liliyana mengungkapkan bahwa setiap bulannya, jumlah pengunjung bulanan Rumah Makan Bumbu Desa Ciledug semakin meningkat dan terutama mereka datang ke restoran tersebut karena adanya pesan promosi yang mereka dengar dari radio Mersi FM dan pesan short message service (SMS). Penelitian kedua yang penulis gunakan adalah penelitian yang dilakukan oleh Rotumiar Pasaribu pada tahun 2020 dengan judul "Mengoptimalkan Media Online Sebagai Solusi Promosi Pemasaran UMKM di Semarang Saat Pandemi Covid-19”. Dalam penelitiannya, Pasaribu menyatakan bahwa UKM diuntungkan dengan pemanfaatan media online sebagai alat komunikasi pemasaran. Selain itu, lanjutnya, melalui media online, UKM dapat dengan mudah berkomunikasi dengan pelanggannya tanpa harus bertatap muka langsung.

Berangkat dari dua studi yang telah disebutkan, penelitian ini bertujuan untuk mengetahui lebih dalam bagaimana 
pemanfaatan media sosial sebagai alat utama bisnis $F \& B$ dalam mempertahankan eksistensinya selama pandemi, khususnya pada periode PSBB. Karena masyarakat sekarang hidup di era "New Normal", di mana dapat dikatakan bahwa masyarakat sekarang hidup 'berdampingan' dengan virus, transformasi bisnis perlu dilakukan. Transformasi bisnis merupakan proses perubahan yang komprehensif dimana perusahaan perlu memposisikan diri dengan tujuan agar perusahaan dapat menjadi yang terbaik dalam menjawab tantangan bisnis baru yang menghadang atau menghadapi lingkungan bisnis yang berubah (Fachrunnisa, 2020).

Konsep Sate Taichan "Goreng" awalnya diciptakan pada tahun 2016 dan setelah melalui pengembangan bisnis dan pembahasan, restoran Sate Taichan "Goreng" kemudian mendirikan cabang pertamanya di Bandung. Konsep awal dari Sate Taichan "Goreng" sendiri adalah menghadirkan kuliner sederhana sate taichan yang berbeda dengan sate tradisional dengan tidak menggunakan bumbu kacang, melainkan menggunakan sambal yang sudah dijual secara tradisional dengan gerobak hingga tingkat atas. konsep kuliner, yaitu membawanya ke level restoran. Sate Taichan "Goreng" mendapat perhatian yang sangat besar saat pertama kali diperkenalkan ke publik, terlihat dari antusiasme para milenial yang datang ke restoran tersebut. Berkat antusiasme masyarakat yang positif, Sate Taichan “Goreng” kini telah memiliki lima cabang operasional yang tersebar di Jakarta, Depok, Tangerang, Bekasi, dan Bandung.

Dengan pandemi yang mengganggu praktik bisnis di hampir setiap sektor, tim manajemen Sate Taichan "Goreng" didorong untuk beradaptasi dan menciptakan inovasi bisnis agar dapat bertahan. Selain itu, dengan adanya regulasi PSBB yang membatasi pengunjung di restoran dan standar "New Normal", Sate Taichan "Goreng" juga perlu melakukan penyesuaian dalam menjalankan operasional bisnisnya sehari-hari. Berdasarkan hasil survei beberapa institusi yang telah dijelaskan sebelumnya, sektor industri $F \& B$ merupakan salah satu sektor industri yang mengalami dampak luar biasa dari pandemi Covid-19. Akibat aturan PSBB, di mana makan di restoran dilarang keras dan jam malam diberlakukan, Sate Taichan "Goreng" juga mengalami penurunan omzet usaha yang cukup signifikan. Penulis membandingkan data penjualan online pada bulan April dan Mei 2019 dengan 2020 pada saat kebijakan PSBB pertama kali diterapkan di beberapa daerah, termasuk Jabodetabek. Jika merujuk kembali kepada April dan Mei 2020 ketika Indonesia dapat dikatakan berada pada fase awal pandemi, selain pemberlakuan kebijakan PSBB yang 
kemudian memberikan dampak yang besar kepada seluruh aspek kehidupan masyarakat, masyarakat Indonesia pada saat itu juga turut dilanda gelombang disinformasi yang merugikan. Banyaknya informasi yang diragukan validitasnya menyebabkan terjadinya panic buying dan masyarakat kemudian enggan membeli makanan dari luar, mereka merasa lebih baik memasak makanan sendiri di rumah. Akibatnya, para pelaku bisnis F\&B kemudian diperhadapkan dengan situasi baru yang memaksa mereka untuk melakukan banyak penyesuaian dan inovasi bisnis. Arifin selaku manajer operasional Sate Taichan "Goreng" memberikan pernyataan,

"Regulasi PSBB sangat mengejutkan kami sebagai pelaku bisnis F\&B. Kami tentu tidak siap menghadapi hal-hal dan dampak apa saja yang menimpa kami. Tetapi sebagai pelaku bisnis, kami menyadari bahwa perlu tindakan segera untuk dapat bertahan hidup"

(Arifin, komunikasi pribadi, 202125 Januari).

Sementara menurut Fanny Tampubolon, salah satu pelanggan setia Sate Taichan "Goreng" memberikan pernyataan,

"Kami takut membeli produk $F \& B$ yang tidak diproduksi dari rumah karena kami tidak tahu persis bagaimana restoran menyiapkan produknya. Apakah cukup aman dan higienis? Apakah karyawan restoran mematuhi protokol kesehatan? Apakah udara restoran sudah terkontaminasi virus? Banyak sekali faktor yang membuat kami takut untuk membeli produk $F \& B$ "

(Tampubolon, komunikasi pribadi, 202125 Januari).

Disebabkan oleh kebijakan pembatasan sosial yang baru, pendapatan Sate Taichan "Goreng" pada bulan April menurun hingga 50\%, namun karena tindakan langsung diambil, tim berhasil mengamankan posisi yang lebih stabil dengan melakukan beberapa tindakan preventif dan inovatif. untuk menjaga agar bisnis tetap bertahan. Tim Sate Taichan "Goreng" juga memastikan bahwa pelanggan memiliki pengalaman yang sama dalam menikmati produknya dengan cara yang sama saat mereka menikmati produknya langsung di restorannya. Di sisi lain, dalam hal strategi komunikasi pemasaran restoran, tim pemasaran Sate Taichan "Goreng" mengambil pendekatan yang berbeda dalam mempromosikan merek itu sendiri. Memahami bahwa target pasar adalah kaum milenial yang terekspos dengan media digital (Instagram dan Whatsapp), semua aktivitas komunikasi 
pemasaran didorong ke kedua platform tersebut. Selain itu, untuk menjaga loyalitas dan kepercayaan konsumen, terutama pada saat wabah virus melanda, Sate Taichan "Goreng" juga menjaga kualitas dan kebersihan produknya dengan menunjukkan transparansi dalam proses penyiapan dan penyajian produk.

Menurut Kotler dan Keller (2016), komunikasi pemasaran merupakan sarana yang digunakan oleh perusahaan untuk menginformasikan, membujuk, dan mengingatkan konsumen, baik secara langsung maupun tidak langsung, tentang produk dan merek yang mereka jual. Sedangkan Kusniadji (2016) menjelaskan bahwa kegiatan komunikasi pemasaran adalah kegiatan yang bertujuan untuk memperkenalkan, menjalin dan menciptakan interaksi antara perusahaan dengan mitra bisnis dan konsumen dengan kegiatan tersebut, atau merupakan upaya untuk mengkomunikasikan perusahaan, produk atau jasa kepada pihak luar (mitra bisnis, pemasok dan konsumen).

Secara konseptual terdapat empat (4) komponen yang termasuk dalam bauran pemasaran atau yang dikenal dengan 4P (Kaporoh, 2019), diantaranya sebagai berikut: (1) Produk merupakan gabungan dari produk dan jasa perusahaan yang ditawarkan kepada pasar, yang meliputi: kualitas, desain, bentuk, merek dan kemasan produk, (2) Harga, banyak harga terhadap produk atau jasa yang dibayar, (3) Tempat adalah kegiatan yang dilakukan oleh perusahaan untuk membuat suatu produk sehingga dapat diperoleh dan tersedia bagi konsumen sasaran, (4) Promosi, kegiatan yang dilakukan oleh perusahaan untuk mengkomunikasikan keunggulan produk dan membujuk konsumen sasaran untuk membelinya. Pada dasarnya, strategi pemasaran berfokus pada tujuan jangka panjang perusahaan yang melibatkan perencanaan program pemasaran yang mendalam, terukur, dan dapat ditindaklanjuti untuk mencapai tujuan perusahaan. Perusahaan sangat bergantung pada strategi pemasaran untuk merancang lini produk atau jasanya, termasuk produk dan layanan baru (Hermawan, 2012). Dalam merencanakan dan melaksanakan setiap aktivitas pemasaran, pemasar akan selalu bersinggungan dengan komunikasi pemasaran karena merupakan bagian dari marketing strategy itu sendiri.

Berasal dari kata "Communicare", menurut Hovland (dalam Effendy, 2011), komunikasi adalah upaya sistematis untuk merumuskan dengan tepat prinsip-prinsip transmisi informasi dan pembentukan opini dan sikap. Sedangkan menurut West dan Turner (2017), komunikasi adalah proses sosial dimana individu menggunakan simbol untuk membangun dan menafsirkan makna di sekitar lingkungannya. 
Singkatnya, hal esensial dalam sebuah proses komunikasi yang perlu ditekankan adalah pemahaman antar sesama pelaku komunikasi yang terlibat, yaitu pengirim pesan (sender) dan penerima pesan (receiver).

Secara teoritis, Tjiptono (2014) menyatakan bahwa komunikasi pemasaran memegang peranan penting sebagai bagian dari bauran pemasaran suatu merek. Di sisi lain, Soemanegara (dalam Hazizah, dkk, 2016) menjelaskan bahwa komunikasi pemasaran merupakan kegiatan komunikasi satu pihak yang bertujuan untuk menyampaikan pesan kepada konsumen dengan menggunakan berbagai jenis media yang selanjutnya proses komunikasi tersebut diharapkan mengarah pada tiga tahap. perubahan; (1) Perubahan pengetahuan - pada tahap ini, pemasar fokus pada promosi produk / layanan dengan menginformasikan merek, fungsi produk / layanan dan kemasan, (2) Perubahan sikap - tahap ini dipengaruhi oleh tiga komponen (kognisi pelanggan, kasih sayang, dan konasi), (3) Perubahan perilaku - tahap ini adalah tahap terakhir di mana pelanggan diharapkan untuk membeli dan tetap setia pada produk / layanan yang dipromosikan, juga mencegah mereka beralih ke merek lain. Selanjutnya dalam ruang lingkup komunikasi pemasaran, pemilihan media merupakan jembatan penyeberangan pesan-pesan promosi untuk disampaikan kepada konsumen sasaran dan memegang peranan penting karena mempengaruhi cara konsumen menerima dan menyampaikan pesan promosi. Oleh karena itu, pemasar melakukan proses pemilihan media berdasarkan beberapa faktor, seperti produk yang akan dipasarkan, target pasar, waktu pengiriman pesan dan biaya promosi (Pasaribu, 2020).

Selain itu, menurut Kotler dan Keller (2016), komunikasi pemasaran terdiri dari delapan model komunikasi: (1) Advertising merupakan kegiatan mempromosikan ide, barang, atau layanan dengan membayar sponsor melalui media cetak, broadcast, jaringan, elektronik, maupun display media, (2) Sales promotion merupakan aktivitas jangka pendek untuk meningkatkan penjualan produk atau layanan, mencakup promosi konsumen seperti pemberian sample, kupon, premium, (3) Event and Experiences yaitu aktivitas sponsorship dan pembuatan program untuk menciptakan interaksi dengan konsumen, mencakup olahraga, hiburan, seni, dan acara lainnya yang sifatnya tidak formal, (4) Public relation and publicity adalah upaya yang bertujuan untuk menjaga citra positif perusahaan dimata publik serta menjaga hubungan erat dengan mereka. (5) Direct marketing merupakan metode penjualan dengan sistem pemasaran langsung tanpa adanya pihak ketiga sebagai perantara, sehingga 
proses penawaran maupun transaksi jual beli bisa terjadi sangat dinamis, (6) Interactive marketing merupakan strategi pemasaran dengan komunikasi dua arah, sehingga memungkinkan konsumen terhubung langsung dengan perusahaan dengan tujuan meningkatkan kesadaraan, meningkatkan citra, dan mendapatkan penjualan produk atau layanan secara langsung atau tidak langsung, (7) Word of Mouth Marketing promosi berupa rekomendasi dari mulut ke mulut, tertulis, atau berlangsung dengan komunikasi elektronik tentang pengalaman penggunaan produk yang menentukan keputusan dalam pembelian, (8) Personal selling interaksi langsung antar individu produsen kepada calon pembeli, dengan tujuan menjelaskan, menjawab pertanyaan, dan mempengaruhi calon pembeli hingga terjadi suatu penjualan. Selain itu, dengan semakin banyaknya pengguna internet selama pandemi, ditunjukkan oleh survei dari Ipsos bahwa dari seluruh pengguna e-commerce, $22 \%$ responden survei mengaku telah menggunakan e-commerce untuk membeli produk $F \& B$ (Ipsos, 2020). Survei tersebut menjadi bukti bahwa akselerasi teknologi digitalisasi yang dianggap 'disebabkan' oleh pandemi merupakan peluang untuk mengatasi salah satu masalah utama yang dihadapi industri $F \& B$ pada masa pandemi, yaitu masalah pemasaran. Sebagaimana dijelaskan di atas, penelitian ini dilakukan dengan tujuan untuk mengetahui ketahanan hidup $F \& B$ pasca pandemi dengan menggunakan studi kasus Sate Taichan "Goreng". Penelitian ini diharapkan dapat menggambarkan analisis strategi komunikasi pemasaran Sate Taichan "Goreng" melalui kegiatan pemasaran yang dilakukan oleh tim pemasaran restoran.

\section{METODOLOGI}

Penelitian ini menggunakan pendekatan kualitatif deskriptif sebagai metode penelitian. Menurut Sugiyono (2016), metode penelitian kualitatif adalah suatu penelitian yang digunakan untuk mengkaji benda-benda alam dimana peneliti berperan sebagai instrumen kunci dan teknik pengumpulan datanya dilakukan secara kombinasi, dan dimaksudkan untuk lebih menekankan pada makna objek penelitian tersebut. generalisasi.

Dalam penelitian ini, peneliti mengkaji implementasi bauran promosi dalam bisnis kuliner selama pandemi Covid-19. Objek penelitian ini adalah strategi komunikasi pemasaran yang dilakukan oleh tim Sate Taichan "Goreng" dan pengumpulan data dilakukan dengan observasi, dilanjutkan dengan wawancara mendalam studi pustaka.

Peneliti langsung hadir di Restoran Sate Taichan "Goreng" cabang Tebet pada tanggal 25 Januari 2021. Di pertemuan itu, peneliti langsung mengadakan wawancara 
kepada Arifin selaku Manager Operasional Restoran Sate Taichan "Goreng”. Peneliti melakukan wawancara tentang kegiatan bisnis Restoran Sate Taichan "Goreng" terutama selama pandemi. Selain itu peneliti juga mewawancarai seorang konsumen Restoran Sate Taichan “Goreng”, yaitu F Tampubolon dari Tebet.

Dalam penelitian ini, peneliti menggunakan teknik analisis data Miles \& Huberman (dalam Bugin, 2010) yang terdiri dari empat (4) tahap yaitu, pengumpulan, reduksi, penyajian data, dan penarikan kesimpulan berdasarkan seluruh rangkaian kegiatan proses teknik analisis data yang dilakukan.

\section{HASIL DAN PEMBAHASAN}

Sebagaimana dipaparkan secara singkat sebelumnya, sebagai salah satu pemain bisnis F\&B, Sate Taichan "Goreng" turut mengalami dampak yang besar akibat dari pemberlakuan kebijakan PSBB. Peneliti melakukan perbandingan omzet pendapatan restoran pada bulan April dan Mei 2019 dengan 2020 ketika pada saat kebijakan PSBB baru diberlakukan di beberapa wilayah, termasuk Jabodetabek.
Tabel 1. Omzet Pendapatan Restoran Sate Taichan "Goreng" bulan April dan Mei 2019 dibandingkan tahun 2020

\begin{tabular}{ccc}
\hline Tahun & $\begin{array}{c}\text { Omzet bulan } \\
\text { April (Rp) }\end{array}$ & $\begin{array}{c}\text { Omzet bulan } \\
\text { Mei (Rp) }\end{array}$ \\
\hline 2019 & $\operatorname{Rp~534.007.906~}$ & $\mathrm{Rp} \mathrm{313.744.721}$ \\
2020 & $\mathrm{Rp} \mathrm{313.744.721}$ & $\mathrm{Rp} \mathrm{174.162.210}$ \\
& 41,2 & 44,4 \\
$\begin{array}{c}\text { Omzet } \\
\text { dalam }\end{array}$ & & \\
persentase & & \\
$(\%)$ & &
\end{tabular}

Sumber: Arifin, 2021 Januari 25

Pada Tabel 1. Menampilkan data omzet yang diperoleh restoran Sate Taichan “Goreng” untuk pemesanan secara online. Data yang diambil membandingkan antara pendapatan sebelum pandemi pada tahun 2019 dengan waktu pandemi pada tahun 2020. Data yang dipilih oleh peneliti adalah pada bulan April dan Mei saat peraturan PSBB pertama kali diterapkan di beberapa daerah, termasuk Jabodetabek. Saat itu, ditambah dengan fenomena disinformasi yang sangat luas yang dialami oleh banyak orang masyarakat sangat ketakutan dan minat pelanggan untuk membeli produk $F \& B$ dari restoran sangat rendah. Maraknya peredaran informasi yang diragukan validitas nya, panic buying, dan minimnya pemahaman masyarakat akan virus model baru kemudian memaksa para pelaku bisnis F\&B untuk melakukan penyesuaian dan inovasi lebih lanjut demi keberlangsungan dan ketahanan bisnis.

Lebih dalam, objek penelitian ini adalah strategi komunikasi pemasaran yang dilakukan oleh tim Sate Taichan "Goreng" selama periode PSBB dengan melakukan 
analisis mendalam terhadap data yang terkumpul.

Kotler dan Keller (2016) menggunakan istilah bauran komunikasi pemasaran untuk kegiatan pemasaran yang berkaitan dengan promosi. Bauran komunikasi pemasaran ini terdiri dari 8 (delapan) model komunikasi utama; periklanan, promosi penjualan, acara dan pengalaman, hubungan masyarakat dan publisitas, pemasaran langsung, pemasaran interaktif, pemasaran dari mulut ke mulut, dan penjualan pribadi. Peneliti menggunakan konsep bauran komunikasi pemasaran yang dikemukakan oleh Kotler dan Keller sebagai acuan wawancara dengan tim restoran Sate Taichan "Goreng".

Tabel 2. Bentuk Komunikasi Pemasaran Restoran Sate Taichan "Goreng"

\begin{tabular}{ll}
\hline Bauran & Implementasi \\
Komunikasi & Komunikasi \\
Pemasaran & Pemasaran untuk \\
Kotler dan & Sate Taichan \\
Keller, 2016) & "Goreng" Restoran \\
\hline Periklanan & Melayani iklan \\
& produk melalui \\
& Celebrity \\
& Endorser; \\
& Pembuatan brosur \\
& secara digital; \\
& Bekerja sama \\
& dengan aplikasi \\
& kasir "Pawoon" \\
\hline
\end{tabular}

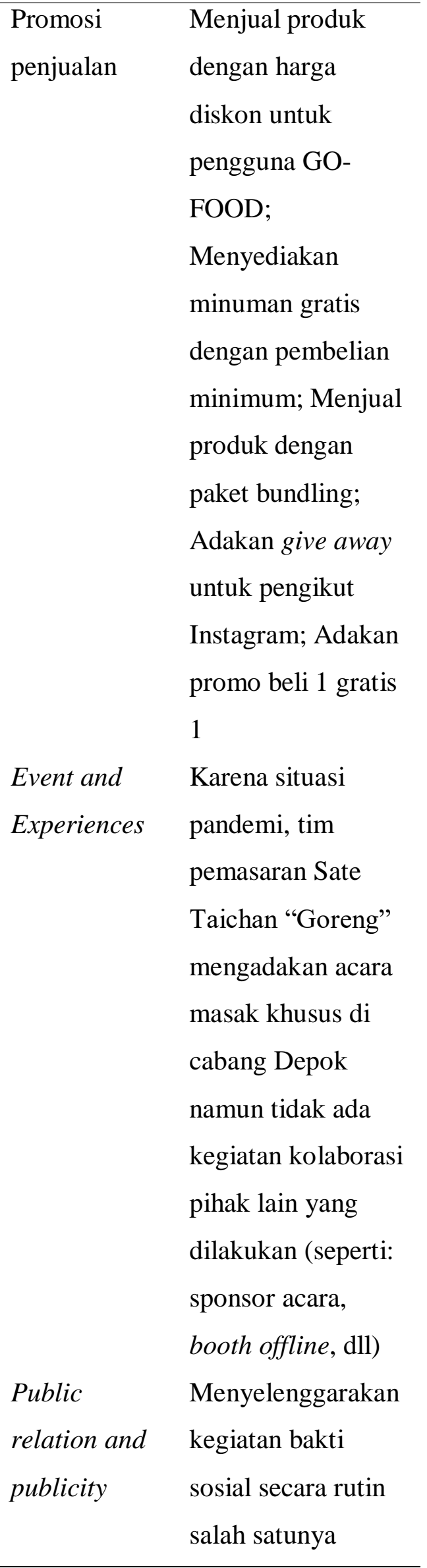




\begin{tabular}{|c|c|}
\hline \multirow{11}{*}{$\begin{array}{l}\text { Pemasaran } \\
\text { interaktif }\end{array}$} & dengan \\
\hline & membagikan \\
\hline & makanan gratis \\
\hline & kepada para driver \\
\hline & Go-Jek \\
\hline & Penggunaan media \\
\hline & sosial Instagram \\
\hline & dan Facebook \\
\hline & untuk pemasaran \\
\hline & interaktif kepada \\
\hline & konsumen \\
\hline \multirow{11}{*}{$\begin{array}{l}\text { Word of } \\
\text { Mouth } \\
\text { Marketing }\end{array}$} & WOM dilakukan \\
\hline & oleh konsumen, \\
\hline & dimana konsumen \\
\hline & memberikan \\
\hline & umpan balik \\
\hline & melalui media \\
\hline & sosial atau chat \\
\hline & messenger; WOM \\
\hline & menggunakan opini \\
\hline & selebriti sebagai \\
\hline & pembawa pesan \\
\hline \multirow{11}{*}{$\begin{array}{l}\text { Pemasaran } \\
\text { langsung }\end{array}$} & Penggunaan \\
\hline & whatsapp chat \\
\hline & messenger, email \\
\hline & dan telepon untuk \\
\hline & memasarkan \\
\hline & produk ke \\
\hline & konsumen \\
\hline & didukung oleh \\
\hline & admin layanan \\
\hline & pelanggan yang \\
\hline & berdedikasi \\
\hline
\end{tabular}

\begin{tabular}{ll}
\hline Penjualan & Tim layanan \\
pribadi & pelanggan yang \\
& berdedikasi yang \\
& juga menggantikan \\
& peran tenaga \\
& penjualan dalam \\
& melayani transaksi
\end{tabular}

Sumber: Arifin, 2021 Januari 25

Model pertama yang digunakan restoran Sate Taichan "Goreng" adalah iklan. Menurut Lupiyoadi (2013) periklanan merupakan salah satu bentuk komunikasi impersonal yang digunakan oleh perusahaan dalam mengkomunikasikan produknya, baik barang maupun jasanya. Daripada menggunakan iklan konvensional dengan menempatkannya pada media massa seperti TV dan billboard yang membutuhkan biaya tinggi, Sate Taichan "Goreng" menggunakan pendekatan menggunakan Key Opinion Leaders (KOL) atau dalam hal ini celebrity / celebgram endorsers untuk mengiklankan produk yang mereka jual. Bagi pengguna media sosial Instagram, seseorang yang populer di aplikasi biasanya dijadikan sebagai Celebrity Endorser dan sering disebut sebagai "celebgram". Peran selebritis dalam pemasaran membuat produk / jasa mudah dikenali dan dikenali oleh masyarakat karena para seleb itu sendiri sudah terkenal dan terkenal (Rejeki, DS, dkk, 2020). Beberapa Celebrity Endorser yang pernah terlibat dalam 
pemasaran Sate Taichan "Goreng" adalah Steven Lukita, Eric Ekos, Fadil Jaidi, Clarissa Putri, dan Rachel Vennya. Selebritis endorser umumnya dipilih berdasarkan ketertarikannya pada kelezatan kulinernya sehingga bisa mempromosikan Sate Taichan "Goreng" dengan cara terbaik. Dalam hal mengiklankan produk secara digital, STG membuat Tim Kreatif yang berperan dalam membuat kontenkonten digital yang sesuai tren dan dapat menarik pelanggan. STG juga melakukan kerjasama dengan kasir "Pawoon" untuk memperluas periklanan secara digital. Secara langsung Pawoon mempermudah pembayaran digital, namun secara tidak langsung pihak Pawoon juga melakukan promosi terhadap bisnis STG karena memperkenalkan STG sambil menunjukkan bahwa STG juga menggunakan layanan kasir dari Pawoon.

Model kedua yang digunakan restoran Sate Taichan "Goreng" adalah Sales Promotion. Menurut Lupiyoadi (2013), promosi penjualan adalah segala aktivitas yang dimaksudkan untuk meningkatkan arus barang atau jasa dari produsen ke penjualan akhir mereka. Pernyataan Lupiyoadi ini sejalan dengan pernyataan Kotler dan Keller (2016, 266): "Promosi penjualan berasal dari tujuan komunikasi, yang bersumber dari tujuan dasar pemasaran produk. Bagi konsumen, tujuan tersebut antara lain mendorong lebih seringnya pembelian atau pembelian dari unit berukuran lebih besar di antara pengguna. Tujuan dari promosi penjualan menurut Kotler dan Armstrong $(2016,452)$ yaitu penjual dapat menggunakan promosi konsumen untuk mendorong pembelian pelanggan jangka pendek atau meningkatkan keterlibatan merek pelanggan.

Dalam praktiknya, Sate Taichan "Goreng" sudah sangat aktif melakukan promosi penjualan melalui akun Instagram resminya (@taichangoreng) bahkan sebelum pandemi terjadi. Akun Instagram Sate Taichan "Goreng" telah mendapatkan badge verifikasi centang biru resminya yang merupakan simbol yang akan membantu pengguna Instagram menemukan public figure, selebritis Instagram, dan brand resmi dengan mudah, pada dasarnya dengan status terverifikasi akan meningkatkan kepercayaan pengguna dalam suatu akun.

Tabel 3. Persentase pengikut Instagram @ taichangoreng periode Mei - Desember 2020

\begin{tabular}{ccc}
\hline Bulan & $\begin{array}{c}\text { Jumlah } \\
\text { pengikut } \\
\text { yang } \\
\text { ditambahk } \\
\text { an setiap } \\
\text { bulan }\end{array}$ & $\begin{array}{c}\text { Persentase } \\
\text { peningkatan } \\
\text { pengikut }\end{array}$ \\
& \\
& 750 & $35 \%$ \\
Mei & 450 & $25 \%$ \\
\hline
\end{tabular}




\begin{tabular}{ccc}
\hline Juli & 480 & $30 \%$ \\
Agustus & 775 & $30 \%$ \\
September & 750 & $35 \%$ \\
Oktober & 1.085 & $30 \%$ \\
November & 750 & $35 \%$ \\
Desember & 1.147 & $40 \%$ \\
Total & 6.187 & \\
penambahan & & \\
pengikut & &
\end{tabular}

Sumber: Arifin, 2021

Tabel 3. Menunjukkan peningkatan jumlah pengikut Instagram pada periode Mei hingga Desember 2020. Selama periode Mei - Desember 2020 ditemukan jumlah pengguna meningkat sebesar 6.187 yang berarti selain pandemi, Sate Taichan "Goreng" Tim telah berhasil menjaga eksistensi digital merek tersebut.

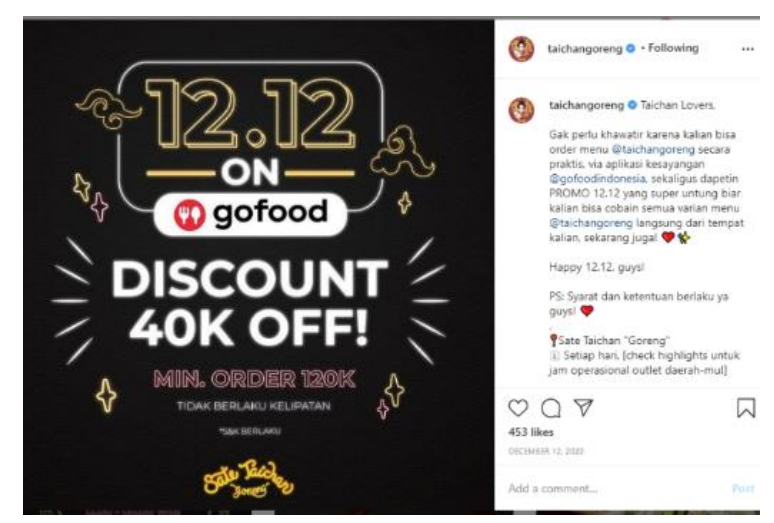

Gambar 1 Contoh kegiatan promosi penjualan yang dilakukan oleh Sate Taichan "Goreng" restoran di mitra gofood

Pada Gambar 1 Sate Taichan "Goreng" yang diumumkan di Instagram, dalam rangka memperingati Hari Belanja Online Nasional (Harbolnas), mereka mengadakan promo spesial 11.11 pada 11 November 2020 dan promo spesial 12.12 pada 12 Desember 2020 bekerja sama dengan GoFood. Inisiatif kegiatan promosi penjualan lainnya yang dilakukan oleh Sate Taichan "Goreng" adalah paket bundling dan promo spesial 'buy 1 get $l^{\prime}$ untuk followers Instagram mereka.

Selain melakukan promosi penjualan online, restoran Sate Taichan "Goreng" juga melakukan promosi penjualan untuk dine-in. Sejak 10 Juni 2020, restoran Sate Taichan "Goreng" telah membuka restorannya untuk dine-in service sebagaimana yang diizinkan oleh pemerintah. Promosi khusus seperti promosi khusus Hari Kemerdekaan hanya untuk makan di makan juga dilakukan. Pelanggan dapat datang ke cabang Sate Taichan "Goreng" mana saja dan mendapatkan diskon $8 \%$ untuk dine-in pada pukul 11.00-13.00 WIB, diskon $17 \%$ pada pukul 15.00-17.00 WIB, dan diskon $45 \%$ pada pukul 22.00-00.00 WIB.

Model komunikasi pemasaran ketiga adalah Peristiwa dan Pengalaman (Event and Experiences). Secara konseptual menurut Kotler dan Keller (2016) mendefinisikan event dan pengalaman adalah kegiatan dan program yang disponsori perusahaan yang dirancang untuk menciptakan interaksi atau interaksi yang berkaitan dengan merek tertentu. Karena situasi pandemi, Sate Taichan 
"Goreng" tidak melakukan kolaborasi dengan pihak lain dalam bentuk acara seperti yang biasa dilakukan tim. Namun daya tarik untuk menarik pelanggan dan hanya dilakukan di cabang Depok untuk jangka waktu tertentu adalah acara masak khusus yang disebut "Taichan Gila" di mana pelanggan dapat dengan mudah menyaksikan juru masak Sate Taichan “Goreng" melakukan atraksi yang tidak biasa dalam memasak produk mereka secara langsung, namun masih di bawah protokol kesehatan yang ketat untuk memastikan kebersihan produk.

Model komunikasi pemasaran keempat adalah Hubungan Masyarakat dan Publisitas (Public relation and publicity). Yang dimaksud dengan public relations atau publisitas adalah berbagai kegiatan atau program yang dirancang oleh perusahaan untuk mempromosikan dan melindungi citra perusahaan dan produk individu (Kotler dan Keller, 2016). Tujuan dari public relations adalah membangun hubungan yang harmonis antara perusahaan dengan pihak lain seperti masyarakat. Sedangkan publisitas adalah penyampaian informasi yang dirancang untuk membangkitkan minat yang lebih tinggi pada individu atau perusahaan melalui media informasi tanpa mengeluarkan uang karena besarnya kepentingan publik (Heryanto \& Rumaru, 2015). Tim Public Relation berperan dalam membangun hubungan dengan konsumen dengan memperhatikan publisitas.

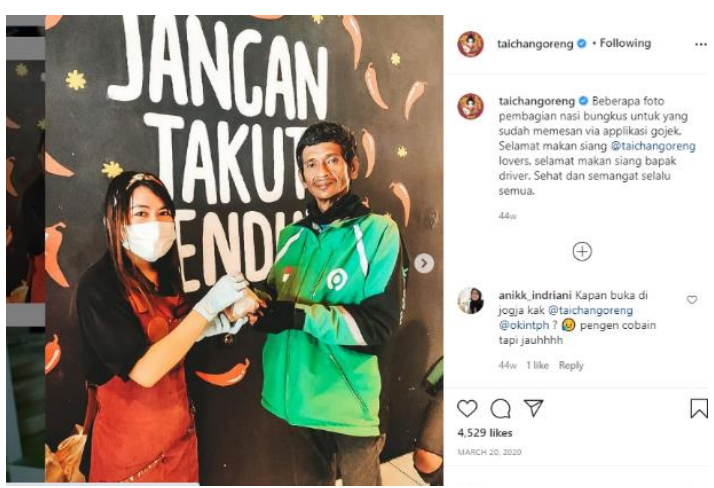

Gambar 2. Distribusi beras kemasan untuk pengemudi Go-Food yang sedang mengambil pesanan online Sate taichan "Goreng" dari pelanggan

Sebagai bagian dari inisiatif Public Relation (PR) Sate Taichan "Goreng”, Sate Taichan "Goreng" membagikan beras kemasan kepada para driver Go-Food yang telah menerima pesanan online setiap hari selama PSBB dan kini pendistribusiannya dilakukan setiap hari Jumat. Kegiatan pemberian nasi kemasan yang dilakukan oleh Sate Taichan “Goreng” ini merupakan bentuk dukungan kepada para driver ojek online sekaligus untuk menjaga citra positif Sate Taichan "Goreng" sebagai sebuah brand.

Selain inisiatif distribusi, inisiatif PR lain yang telah dilakukan oleh tim Sate Taichan "Goreng" adalah tim Customer Service yang berdedikasi dan tersedia 24 jam penuh dalam merespon respon atau keluhan konsumen. Kegiatan ini bertujuan untuk memberikan pengalaman konsumen 
yang terbaik meskipun telah terjadi pandemi serta terjadinya krisis komunikasi preventif yang dapat mempengaruhi penjualan.

Model komunikasi pemasaran kelima yang dilakukan oleh Sate Taichan "Goreng" adalah Pemasaran Interaktif. Pemasaran interaktif adalah aktivitas dan program online yang dirancang untuk melibatkan pelanggan atau prospek dan secara langsung atau tidak langsung meningkatkan kesadaran, meningkatkan citra, atau menciptakan penjualan produk dan layanan (Kotler dan Keller, 2016). Dengan kehadiran internet dan dampaknya terhadap kehidupan manusia dengan meruntuhkan proses interaksi manusia dan membuat dunia tampak tanpa batas, para pemasar membidik konten keterlibatan di seluruh media sosial untuk mendapatkan lebih banyak perhatian pelanggan. Melalui platform Instagram-nya, Sate Taichan "Goreng" mendorong konten yang lebih interaktif dengan pelanggan dengan melakukan survei atau polling online dengan konten berbeda secara berkala. Beberapa polling online yang dilakukan terdiri dari: "Apa menu favoritmu di Sate Taichan" Goreng "?”, “Apakah kamu rindu makan bersama pasukan kami?", dan lainnya. Hasil survei digunakan untuk melakukan evaluasi terhadap produk STG. Adapun hasil survei online ini tidak dapat dijabarkan lebih lanjut oleh tim Sate
Taichan "Goreng" karena kebijakan perusahaan. Selain itu, inisiatif interaktif lainnya yang dilakukan oleh Sate Taichan "Goreng" adalah dengan memberikan promo diskon kepada konsumen yang selama ini aktif melakukan reposting, berkomentar, atau menyukai postingan Sate Taichan "Goreng". Dengan melibatkan konsumen dalam interaksi akan membuat semakin dekat dengan poses pembelian.

Model komunikasi pemasaran keenam yang dilakukan adalah Word of Mouth. Menurut WOMMA (Word of Mouth Marketing Association), Word of Mouth (WOM) merupakan upaya pemasaran yang memicu konsumen untuk berdiskusi, mempromosikan, merekomendasikan, dan menjual produk / merek kita kepada pelanggan lain (Sumardy, et al., 2011). Berdasarkan sifatnya, WOM dapat dibedakan menjadi positif dan negatif. Sebisa mungkin Restoran Sate Taichan "Goreng" mendorong penyebaran WOM yang positif dan menekan atau bahkan menghilangkan WOM negatif yang berdampak negatif terhadap pencapaian target pemasaran. WOM yang positif membentuk image dan opini yang positif pada pelanggan. Sebaliknya, WOM yang negatif dapat memberi image buruk yang dapat merusak image perusahaan. Untuk melakukan penekanan terhadap WOM negatif, STG mempertahankan kualitas produk dan pelayanan yang diberikan. 
Dengan hal itu diharapkan pelanggan mendapat kepuasan dan menyebarkan WOM positif. Penggunaan WOMM yang diberikan dari opini konsumen dan selebriti melalui media online semakin penting karena melalui media online penyebaran informasi menjadi lebih cepat dan luas.

Hasil penelitian menunjukkan bahwa model komunikasi pemasaran, Direct Marketing dan Personal Selling. Pemasaran langsung (direct marketing), penggunaan surat, telepon, faks, email, atau internet untuk berkomunikasi atau meminta tanggapan atau dialog dari pelanggan dan prospek tertentu (Kotler \& Keller, 2016). Sedangkan menurut Belch dan Belch (2013) Komunikasi pribadi individu kepada calon konsumen dalam penjualan pribadi (personal selling) memungkinkan tenaga penjualan untuk menyesuaikan pesan dengan kebutuhan atau situasi pelanggan tertentu. Pemasaran langsung bisa dikatakan hampir sama dengan personal selling, yaitu pemasaran langsung tidak menggunakan tenaga penjual, tetapi menggunakan alat non personal, seperti surat, email, katalog, dan lain-lain. Sedangkan personal selling menggunakan tenaga penjual. Restoran Sate Taichan “Goreng” menggunakan WhatsApp, e-mail, dan layanan obrolan telepon untuk memasarkan produk kepada konsumen untuk pemasaran langsung dan model penjualan pribadi. Database berupa alamat email dan nomor telepon dari pelanggan diperoleh melalui Tim Customer Care Restoran Sate Taichan "Goreng”.

Hasil penelitian menunjukkan bahwa penerapan delapan model komunikasi pemasaran di rumah makan Sate Taichan "Goreng" selama pandemi Covid-19 mengandalkan media online baik secara langsung maupun tidak langsung. Arifin selaku narasumber juga menjelaskan bahwa penurunan kapasitas restoran sesuai protokol kesehatan membuat pendapatan lebih dominan daripada online take away dan delivery order.

Tabel 4. Omzet Pendapatan Transaksi Online dari Restoran Sate Taichan "Goreng” 2020

\begin{tabular}{cc}
\hline Bulan & Omzet Transaksi Online \\
\hline Januari & Rp 93.800 .512 \\
Februari & Rp 95.554.620 \\
Maret & Rp 104.800.438 \\
April & Rp 160.500.021 \\
Mei & Rp 103.801.599 \\
Juni & Rp 154.800 .783 \\
Juli & Rp 133.490.584 \\
Agustus & Rp 149.488.590
\end{tabular}

Sumber: Arifin, 2021

Pada Tabel 4. Menunjukkan adanya peningkatan pemesanan secara online take away dan delivery order. Diketahui bahwa sebelum pandemi terjadi pada bulan Januari 2020 lalu masa pandemi dimulai dari Februari 2020 dan bulan berikutnya. Data menunjukkan nilai omzet pemesanan online pada bulan Februari - Agustus 2020 
selalu lebih besar nilainya dibanding Januari 2020. Hal ini menunjukkan adanya pergeseran perilaku konsumen karena lebih memilih bertransaksi secara online daripada offline. Peneliti melihat ini sebagai fenomena Stay at Home Economy. Fenomena ini juga diungkapkan Menteri Koperasi dan Usaha Kecil dan Menengah Teten Masduki, bahwa wabah Covid-19 akan mengubah tren belanja masyarakat, meski berakhir nanti. Teten Masduki menyatakan bahwa masyarakat telah mengalami perubahan pola konsumsi, dari offline ke online (Prabowo, 2020). Saat ini berbagai kemajuan teknologi bisa ditemukan dimana saja, salah satunya dan yang paling dekat dengan penggunanya adalah ponsel pintar atau smartphone. Berbeda dengan jaman dulu, ponsel hanya bisa digunakan untuk komunikasi terbatas seperti telepon dan pengiriman pesan, saat ini ponsel pintar dilengkapi dengan fasilitas internet dan di dalamnya. Internet dapat membantu memberikan solusi dalam informasi dan komunikasi jarak jauh. Kemudahan dan kepraktisan smartphone inilah yang membuat terjadi pergeseran pola masyarakat, termasuk dalam proses berbelanja. Kondisi pandemi yang mengakibatkan jarak fisik dan sosial mempengaruhi bentuk proses pemasaran yang terjadi. Jika sebelumnya konsumen langsung berbelanja, Situasi pandemi tersebut mengakibatkan konsumen lebih memilih tinggal di rumah dan mengandalkan media pemasaran yang memudahkan proses belanja tanpa kontak fisik. Menurut Yuswohady (2020), stay at home economy akan mampu bertahan dalam menghadapi kemungkinan krisis ekonomi yang paling parah akibat Covid19. Pandemi Covid-19 akan membentuk gaya hidup tinggal di rumah yang akan menjadi normal baru setelah krisis berlalu. Gaya hidup baru ini menjadi dasar pembentukan stay at home economy. Berangkat dari hal tersebut, pandemi akan menciptakan perubahan permanen dalam perilaku konsumen yang mengarah pada pembentukan stay at home economy sebagai new normal. Dengan demikian, pelaku bisnis harus segera melihat peluang dan menerapkan Survival Innovation.

Survival Innovation juga dilakukan oleh restoran Sate Taichan "Goreng" khusus untuk meningkatkan akselerasi adopsi transformasi digital. Transformasi digital adalah perubahan organisasi yang melibatkan manusia, proses, strategi, struktur, melalui penggunaan teknologi dan model bisnis untuk meningkatkan kinerja (MIT \& Campgemini, 2011). Transformasi digital adalah cara yang efektif untuk "menjembatani" antara bisnis melalui penggunaan teknologi. Bentuk transformasi digital yang dilakukan restoran Sate Taichan "Goreng" antara lain melakukan pemesanan pengiriman, bekerjasama 
dengan Pawoon untuk aplikasi pembayaran di kasir, memberikan kemudahan transaksi dengan berbagai media pembayaran elektronik, dan aktif melakukan komunikasi pemasaran online. Menurut McKinsey, perusahaan yang memiliki aset digital ternyata paling siap untuk menangani perubahan yang terjadi, seperti platform e-commerce atau aplikasi logistik dan pengiriman makanan yang dapat mengirimkan bahan makanan dan kebutuhan lainnya lebih cepat dan andal, tanpa kehadiran konsumen secara fisik (TelkomMetra, 2020).

\section{KESIMPULAN}

Berdasarkan hasil penelitian yang telah dijelaskan dan dianalisis pada pembahasan sebelumnya, penulis menarik kesimpulan bahwa komunikasi pemasaran Restoran Sate Taichan "Goreng" dapat dilihat dari delapan model bauran komunikasi pemasaran. bekerjasama dengan aplikasi kasir "Pawoon". Penggunaan Celebrity Endorser dikatakan cukup berpengaruh dalam memasarkan produk. Kemudian untuk digital flyer lebih memudahkan pemasaran untuk wilayah yang lebih luas karena menggunakan internet dan tidak memerlukan biaya. Model kedua adalah promosi penjualan melalui aplikasinya, menjual produk dengan potongan harga ke mitra Go-Food, memberikan minuman gratis dengan minimal pembelian, menjual produk dengan paket bundling, mengadakan give away untuk followers Instagram, mengadakan promo beli 1 gratis 1 , dan menampilkan cook show di cabang Depok. Penerapan model ini lebih dominan pada promosi yang berkaitan dengan harga diskon karena konsumen lebih menyukai promo berdiskon. Dalam mengaplikasikan event and experiences model komunikasi pemasaran, restoran Sate Taichan "Goreng" membagikan makanan kepada para pengemudi GOJEK sebagai bentuk dukungan untuk tetap semangat bertahan di tengah pandemi Covid-19. Model keempat adalah hubungan masyarakat dan publisitas. Penerapan model keempat ini adalah membentuk Tim $P R$ dan Tim Customer Service untuk mendukung komunikasi pemasaran produk khususnya brand image restoran Sate Taichan "Goreng". Dalam penerapan direct marketing dan personal selling yang menggunakan whatsapp chat messenger, $e$ mail, dan telephone untuk memasarkan produk kepada konsumen. Model pemasaran interaktif memanfaatkan media sosial Instagram dan Facebook untuk pemasaran interaktif kepada konsumen menggunakan survei dan jajak pendapat. Penerapan model word of mouth marketing menggunakan opini konsumen dan selebriti dalam pemasaran produk. Jadi, penerapan 8 model komunikasi pemasaran merupakan 
model yang sudah efektif diterapkan. Hal tersebut ditunjukkan dengan penambahan pengikut di akun Instagram sebanyak 6.187 pada tahun 2020 dan peningkatan pendapatan sejak Agustus 2020. Selain untuk menjaga kualitas dan inovasi menu, Survival Innovation yang dilakukan oleh restoran Sate Taichan "Goreng" adalah melakukan transformasi bisnis digital. Tindakan ini dilakukan untuk mengatasi fenomena stay at home economy yang menunjukkan adanya perubahan pola konsumsi konsumen dari offline menjadi online.

\section{DAFTAR PUSTAKA}

Arifin. (2021, 25 Januari). Personal Interview. Arifin, D. (2020, April 13). Presiden Tetapkan COVID-19 Sebagai Bencana Nasional. Diakses dari https://bnpb.go.id/berita/presidentetapkan-covid19-sebagai-bencananasional\#: :text=JAKARTA\%20\%2D\%2 0Presiden\%20Joko\%20Widodo\%20secar a,\%2D19)\%20Sebagai\%20Bencana\%20 Nasional.

Aushaf, R., \& Rina, N. (2020). Pengaruh celebrity endorser terhadap minat beli sate taichan goreng. Jurnal Ilmiah LISKI (Lingkar Studi Komunikasi), 5(2), 103109. Diakses dari https://doi.org/10.25124/liski.v5i2.1739.

Badan Pusat Statistik. (2020). Pertumbuhan ekonomi Indonesia triwulan II-2020. Jakarta, Indonesia: Author

Badan Pusat Statistik. (2020). Analisis hasil survei dampak covid-19 terhadap pelaku usaha. Jakarta, Indonesia: Author

Bayu, D. J. (2020, September 15). 6 Sektor usaha paling terdampak saat pandemi corona. Katadata.co.id. Diakses dari https://databoks.katadata.co.id/datapublis h/2020/09/15/6-sektor-usaha-palingterdampak-saat-pandemi-corona
Belch G.E., \& and Belch M.A. (2013). Advertising and promotion: Anintegrated marketing communications perspective. New York, NY: Mc-Graw Hill Education Bugin, B. (2010). Metode Penelitian Kualitatif. Jakarta: PT Raja Grafindo Persada

Douglas, E., dan Staudenmaier, R. (2020, Februari 1). Apa artinya deklarasi "situasi darurat global" dari WHO ?. DW.com. Diakses dari https://www.dw.com/id/apaartinya-deklarasi-situasi-darurat-globaldari-who/a-52217493

Effendy, O. U. (2011). Ilmu Komunikasi: Teori dan Praktek. Bandung, Indonesia: Remaja Rosdakarya

Fachrunnisa, O. (2020). Human-centered design: Model transformasi bisnis era new normal. Dalam Anam, A. K. \& Nurhidayati (Ed.). Manajemen bisnis di era pandemi covid-19 \& new normal. (Ed. ke-1, pp. 153-171). Unissula Press. Diakses dari http://research.unissula.ac.id/file/publikas i/210499044/1449Ebook-

Webinar_MANAJEMEN_BISNIS_di_M asa_Pandemi_Covid-

19_\&_New_Normal_.pdf

Hakim, R. N. (2020, April 7). Disetujui menkes, psbb dki jakarta mulai berlaku selasa 7 april 2020. Kompas.com. Diakses dari

https://nasional.kompas.com/read/2020/0 4/07/11582841/disetujui-menkes-psbb dki-jakarta-mulai-berlaku-selasa-7-april2020?page $=$ all

Hazizah, D., dkk. (2016). Analisis tiga perubahan komunikasi pemasaran melalui iklan (Studi kualitatif pada iklan naratif online "line - nic and mar"). e-Proceeding of Management, 3(2), 2512-2514. ISSN : 2355-9357

Hermawan, A. (2012). Komunikasi pemasaran. Jakarta, Indonesia: Erlangga

Heryanto, G., \& Rumaru, S. (2015). Komunikasi politik: Sebuah pengantar. Bogor, Indonesia: Penerbit Ghalia Indonesia

Ipsos. (2020). Ipsos flair collection | Indonesia 2020. Jakarta, Indonesia: Author

JAKPAT. (2020). Harbolnas 2020: Big sale event - jakpat survey report. JAKPAT Blog. Diakses dari https://blog.jakpat.net/harbolnas-2020big-sale-event-jakpat-survey-report/ 
Kaporoh, I. V. (2019). Pengaruh bauran komunikasi pemasaran spotify premium terhadap minat beli konsumen [Skripsi, Universitas Katolik Atma Jaya]

Kotler, P., \& Keller, K.L. (2016). Marketing management $5^{\text {th }}$ Edition. New York, NY: Pearson Education

Knickrehm, M., Berthon, B. \& Daugherty, P. (2016). Digital Disruption: The Growth Multiplier, Accenture, Dublin. Diakses dari

https://www.accenture.com/_acnmedia/P DF-4/Accenture-Strategy-

DigitalDisruption-Growth-Multiplier.pdf

Liliyana. (2020). Implementasi bauran promosi pada usaha kuliner restoran bumbu desa ciledug di masa pandemi covid-19. Jurnal AKRAB JUARA, 5(4), 228-243. Diakses dari

http://akrabjuara.com/index.php/akrabjua $\mathrm{ra} /$ article/view/1296

Lupiyoadi, R. (2013). Manajemen pemasaran jasa (Ed. ke-3). Jakarta, Indonesia: Salemba Empat

Moka Indonesia. (2020, Maret 27). Industri F\&B terkena dampak paling signifikan akibat virus corona, sedang pendapatan harian industri ritel terjun bebas. MOKA blog. Diakses dari https://blog.mokapos.com/industri-fbterkena-dampak-paling-signifikan-akibatvirus-corona

NapoleonCat. (2020, Januari). Instagram users in Indonesia. NapoleonCat.com. Diakses dari

https://napoleoncat.com/stats/instagramusers-in-indonesia/2020/01

Pasaribu, R. (2020). Optimalisasi media online sebagai solusi promosi pemasaran umkm di semarang pada masa pandemi covid-19. Jurnal Komunikasi dan Media, 1(1), 3344. Diakses dari https://doi.org/10.24167/jkm.v1i1.2848

Prabowo, D. (2020, April 28). "Stay at home economy" diprediksi jadi tren masa depan. Kompas.com. Diakses dari https://nasional.kompas.com/read/2020/0 4/28/16502341/stay-at-home-economydiprediksi-jadi-tren-masa-depan.

Prakoso, F. A. (2020). Dampak coronavirus disease (covid-19) terhadap industri food \& beverages. Jurnal Manajemen Bisnis $(J M B), \quad 33(2)$. Diakses dari https://ejournal.stieibbi.ac.id/index.php/j $\mathrm{mb} /$ article/view/81
Putwiliani, F. (2021, Januari 26). UPDATE Corona Indonesia 26 Januari 2021: Total 1.012.350 Positif, 820.356 Sembuh, 28.468 Meninggal. Tribun News. Diakses dari https://www.tribunnews.com/corona/202 1/01/26/update-corona-indonesia-26Januari-2021-total-1012350-positif820356-sembuh-28468meninggal?page $=3$

Rejeki, D. S., dkk. (2020). Peran selebgram (selebriti instagram) terhadap minat beli konsumen. Diakses dari http://eprints.uniskabjm.ac.id/1943/1/1\%20ARTIKEL\%20DE SY\%20SRI\%20REJEKI.pdf

Ridhoi, M. A. (2021, Januari 15). Pandemi mengubah masa depan peta pasar tenaga kerja - analisis data katadata. Katadata.co.id. Diakses dari https://katadata.co.id/muhammadridhoi/a nalisisdata/6000175461233/pandemimengubah-masa-depan-peta-pasartenaga-kerja

SMERU. [n.d.]. Ekonomi Digital untuk Siapa? Menuju Ekonomi Digital yang Inklusif di Indonesia. Diakses dari http://smeru.or.id/id/content/ekonomidigital-untuk-siapa-menuju-ekonomidigital-yang-inklusif-di-indonesia

Sugiyono. (2016). Metode penelitian kuantitatif kualitatif dan $R \& D$. Bandung, Indonesia: Alfabeta

Sumardy, M., dkk. (2011). The power of word of mouth marketing. Jakarta, Indonesia: Gramedia Pustaka Utama

Tampubolon, F. (2021, 25 Januari). Personal Interview.

TelkomMetra. (2020, Mei 6). Transformasi digital sebagai strategi untuk bertahan di era covid-19. Telkommetra.co.id. Diakses dari https://www.telkommetra.co.id/en/public ation/insight/transformasi-digital-sebagaistrategi-untuk-bertahan-di-era-covid-19

Tjiptono, F. (2014). Pemasaran jasa (prinsip, penerapan, penelitian). Yogyakarta, Indonesia: ANDI

West, R. L. and Turner, L. H. (2017). Introducing Communication Theory: Analysis and Application $6^{\text {th }}$ Edition. New York, NY: Mc-Graw Hill Education

MIT \& Capgemini. (2011). Digital transformation: a road-map for billiondollar organizations. Diakses dari 
Jurnal PIKMA: Publikasi Media Dan Cinema, Volume 3, No. 2, Maret 2021, hlm 85-106

https://www.capgemini.com/wp-

content/uploads/2017/07/Digital_Transfo

rmation_A_Road-Map_for_Billion-

Dollar_Organizations.pdf

Yuswohady. (2020). “Stay @ home” economy.

Yuswohady.com. Diakses dari

https://www.yuswohady.com/2020/03/25/stay-

home-economy/ 